\title{
A study of malignant tumours in Nigeria by short-term tissue culture ${ }^{1}$
}

\author{
R. J. V. PULVERTAFT
}

The limitations of the paraffin section in the diagnosis of disorders of the reticulo-endothelial system are well known. The reasons are obvious; the cells involved are derived from those which take part in inflammation, so that there is always a problem as to where inflammation ends and neoplasia begins. When a decision is made that a process is malignant, there is the further problem of classification. The pathologist, in such cases, is dealing with a continuous series involving more than one type of cell. Attempts are regularly made in every civilized country to segregate malignant entities of this class. They always fail, and few if any classifications have ever been used by anyone except the author, who is always unable to define precisely the cells of which he is writing or to give a list of synonyms.

Since experience discloses these limitations and since each expert, while assured of his own virtuosity, is unable to name another who is completely reliable, it is reasonable to seek another approach, namely, the study of living cells. The number of variables in the case of fixed and stained tissues are few, although the development of histochemistry and the study of impression smears certainly add to them: the size, shape, and intensity of staining of the nucleus and cytoplasm and the general architecture and nature of supporting structures are examples. The variables in the case of living cells are more numerous and quite different. They include motility and the type of motility; adhesion of cells to each other and to glass; the number and nature of organoids; the refractive index of the nucleus and cytoplasm; the presence or absence of phagocytosis; the speed of autolysis of cells in salt mixtures, and its nature, e.g., by nuclear vacuolation; the reaction of cells to noxious agents; the chromosome pattern; the colonial form of associated cells; the production of fibrinolysis, collagenase, and other identifiable metabolites; the behaviour on prolonged culture. There are many others but none of those listed can be established in sections.

One word of caution is necessary. From all human tissue fibroblasts can readily be grown; they are the weeds in the tissue culturist's garden. The most

${ }^{1}$ Foundation Lecture read before the Association of Clinical Pathologists in October 1964. cursory study of the literature shows that many who have attempted to grow human tumours have grown only fibroblasts. Some recognize this but publish results on the grounds that at least they come from malignant tissue, and indeed cells known as 'fibroblasts' vary greatly. Others fall into the trap of believing that they have isolated the essential malignant cell.

All taxonomy depends on the identification of variables; to establish identity, as in the case, for example, of utilizing a key to mosquitoes, it is necessary to prove that at least one variable is recognized which is uniquely present in the material classified. Finger prints have much in common but the establishment of five variables can convict a suspect; and the presence of one variable in the red cells of an infant may exclude a putative father.

However, all methods of investigation produce their own variables, inherent in the method, not in the material; in histology, these include fixation, processing, and staining. In the study of the living cell the method of collection, the nature of the suspending fluid, the structure of the chamber, and, especially, the time elapsing between explantation and examination are all variables which grossly modify appearances. In both disciplines, individual experience and aptitude introduce personal factors; indeed there is room for suspicion that in all microscopy of 'difficult' specimens fatigue and the hypnotic influence of the brightly illuminated microscope field have much to do with the final opinion. But it can be claimed that in histology variables tend to be quantitative, e.g., the size of the nucleus; in the study of living cells they are qualitative, e.g., motility.

In this communication the words 'tissue culture' appear, but in fact the examinations have much more in common with exfoliative cytology than with the work of Carrel. The problem is not how to culture cells so that they can be subcultured even once but to devise methods so that living cells may be examined over a period rarely longer than 48 hours and often only for an hour.

It is with these considerations in mind that we may approach the study of malignant neoplasms in the Nigerian child. The publication in 1958 by Burkitt first drew attention to the common appearance in 
children in Uganda of a malignant tumour which had exceptional features. It is not my purpose to write a review article; Burkitt's many successors, and indeed his apparent precursors, are here irrelevant; undoubtedly the world-wide interest in the condition, including my own, derives from Burkitt's studies. In Nigeria the condition has been extensively studied by Edington and members of his department (Edington and Maclean, 1964), and particular mention must be made of the detailed and highly significant work of Wright (1963) in Uganda.

The pathology was first studied by O'Conor and Davies (1960) and their findings have been widely confirmed, namely, that the tumour is a type of lymphosarcoma and that frequently phagocytic histiocytes are present which produces a 'starry sky' appearance not, however, confined to this condition. At this point agreement ceases. Some hold that by histological examination, and by the study of impression smears a distinct entity can be established; others that it is a familiar tumour of childhood qualified by its enormously greater frequency of occurrence in Africa. In part because of this difference of opinion the eponym 'Burkitt's tumour' has been often used. Some object because eponyms imply a new and distinct disorder, which has not been proved or disproved; on the other hand all eponyms commemorate an original authority and usually confess ignorance of aetiology and difficulty for the time being in classification.

In fact how common the tumour is outside Africa is quite uncertain. Many agree with ten Seldam (1964) that it is found in New Guinea. Since it was generally overlooked even in Africa before Burkitt, it can be stated without qualification that its recognition depends in part on whether or not doctors know of its existence, and agree on criteria for its recognition, and altogether on whether there are any doctors. In Nigeria there is one doctor for every 50,000 inhabitants; there are many large areas without any doctors, and more still without the radiological and laboratory facilities essential for precise classification. In these circumstances it is easy to get lost in a wilderness of semantics and in futile affirmations of identity and priority. The purpose of the investigation described here was simple; if experienced clinicians, histologists, morbid anatomists, and radiologists agree that a given case falls in a category defined by Burkitt (1958) are the living cells consistently the same? Do they differ in any way from cells observed by me in malignant disease in London? Do they resemble in any way other cells, from any source, studied by the same technique?

This attempt to escape from a static to a dynamic pathology has a distinguished history. The first exponent of tissue culture in England, Strangeways introduced the technique in order to study arthriti오. and Carrel himself to study the healing of wounds $\Rightarrow$ It was used by Russell and Bland (1933) and later by? Lumsden (1963) to study neoplasms of the brain? There is indeed an extensive literature on its use it? the classification of disorders of the haemopoietic and reticulo-endothelial systems and of many neo® plasms.

A background for the study of Burkitt's tumour was available in the study of human pathologica 2 tissue at Westminster Hospital, London (Pulvertaft $\vec{\omega}$ 1959). The existence there of an important radios therapy unit and the association of a children's hospital, together with a special relationship witho the armed forces, gave unusual facilities. Investieu gation covered nearly 20 years and included mosf types of human malignancy with the exception of cerebral neoplasms. Time-lapse cinematographic records were available for comparison with Nigerian? material.

Our technical methods are given in an appendix but the most important innovation was the use of ao specially constructed culture chamber, employings nutrient agar as a base, and mounted on a rotating device with the culture medium. In this way cells car be compressed without damage on the resilient agar $\frac{5}{\delta}$ moreover agar repels all cells and glass attracts them Thus cells can be examined in one optical plane, in $\frac{D}{2}$ meniscus of fluid not more than $50 \mu$ deep. $\operatorname{Im} \underset{\vec{P}}{\vec{P}}$ portant use was also made of the collagen technique of Ehrmann and Gey (1956) since all cells adhere to collagen and only some cells to glass. Observation? must be made in a thermostatically controlled. microscope incubator.

In London three types of malignant disease of the reticulo-endothelial system were commonly studied: The commonest was the lymphosarcoma. No case resembling Burkitt's tumour cytologically was seen? The cells were indistinguishable from normal smale lymphocytes in their size and characteristic motility and non-adhesion to glass; identical cells were seen in chronic lymphatic leukaemia. One abnormality often present was the existence of living cells closely applied to or apparently within histiocytes.

Almost equally common was Hodgkin's disease Enormous cells, often binucleated, rich in granule and filamentous mitochrondria, were often seen, and were not motile; lymphocytes adhered to them, andF they were undoubtedly 'Reed Sternberg' cells; with ${ }^{\text {? }}$ them were polymorphs, rapidly motile monocytes, plasma cells, and eosinophils. Freely motile lympho응 cytes were present, often with exceptionally larges granules.

Reticulo-sarcoma was much more rare. The cellso were enormous, very motile, often multinucleated 
and with prominent nucleoli. In acute lymphatic leukaemia the cells were actively motile with characteristic lymphocytic motility, but were much larger, often showed mitosis, which was never seen in chronic lymphatic leukaemia or lymphosarcoma, and the cytoplasm showed the large granules seen in Hodgkin's disease. Material from lymphosarcoma and chronic lymphatic leukaemia was quite stable in culture, but from Hodgkin's disease and from reticulosarcoma was subject to rapid autolysis. In addition material from other forms of leukaemia, including chloroma and monocytic leukaemia, was examined and showed no resemblance to Burkitt's tumour.

The material from Nigeria comprised over 100 cases of Burkitt's tumour, the majority of which were diagnosed clinically either by Professor R. G. Hendrickse or Mr. V. A. Ngu, although cases were referred from many other clinicians. Professor W. P. Cockshott was responsible for the $x$-ray examinations, and the histological diagnoses were made by Professor G. M. Edington; the necropsies were performed usually by Dr. A. R. Mainwaring and Dr. I. Janota. Many cases with swellings of the jaw or abdomen were later excluded clinically; these, which included such conditions as fibrous displasia of the mandible, neuroblastoma, retinoblastoma, leukaemia, and granulomata, were also examined by tissue cultures and readily excluded. The source of material was usually a biopsy (Fig. 1); post-mortem material is useless.

In 15 cases cells were obtained from ascitic fluid (Fig. 2) and in four from cerebrospinal fluid
(Fig. 3). In my opinion the ascitic fluid should always be examined, as it avoids the necessity of a biopsy. Bone marrow sometimes shows exclusively Burkitt cells (Fig. 4).

It was immediately obvious that the cells were subject to extremely rapid autolysis in salt mixtures at $37^{\circ} \mathrm{C}$. and could not therefore be dispersed by enzymes. This rapid autolysis is characteristic and quite exceptional among neoplastic cells; I have only seen it in Hodgkin's disease, in reticulosarcoma, and in mouse leukaemia. It can be delayed by the addition of human serum.

Both calf and horse serum are noxious to Burkitt cells. Dispersal is best achieved by the use of knives or scissors in culture medium. But in spite of the use of many different variants, e.g., chick and bovine embryo extracts, undiluted ascitic fluid from the patients, relatively aerobic and anaerobic conditions, the use of Hank's Eagles and '199' as salt mixtures, and lowering the temperature the cells are exceedingly reluctant to multiply or even to survive more than a few days in vitro.

When examined freshly on agar or between cover slip and slide, the cells are quite characteristic and different from any cells in the London series. They are considerably larger than small lymphocytes; the size of course depends on the degree of pressure applied. They are markedly granular and lymphocytes are not ; granularity is a most reliable diagnostic feature. The granules are usually intracellular but in addition granules adhere to the circumference externally. The granules appear as vacuoles by Leishman's stain (Fig. 5) and stain by osmic acid.

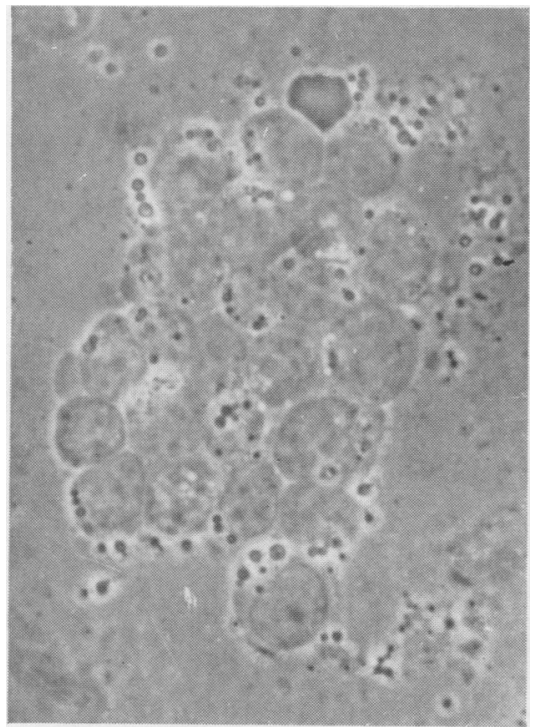

FIG. 1.

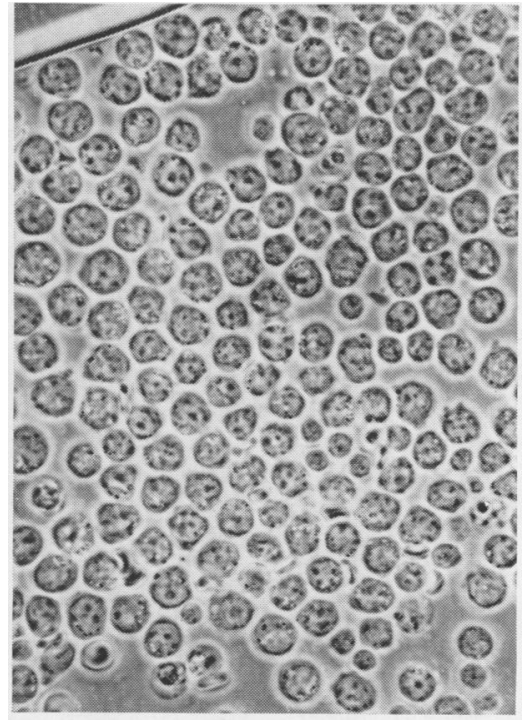

FIG. 2.
FIG. 1. Burkitt cells, fresh preparations on agar from deposit in thyroid $\times 900$.

FIG. 2. Burkitt cells, fresh preparation on glass. Ascitic fluid $\times 450$. 


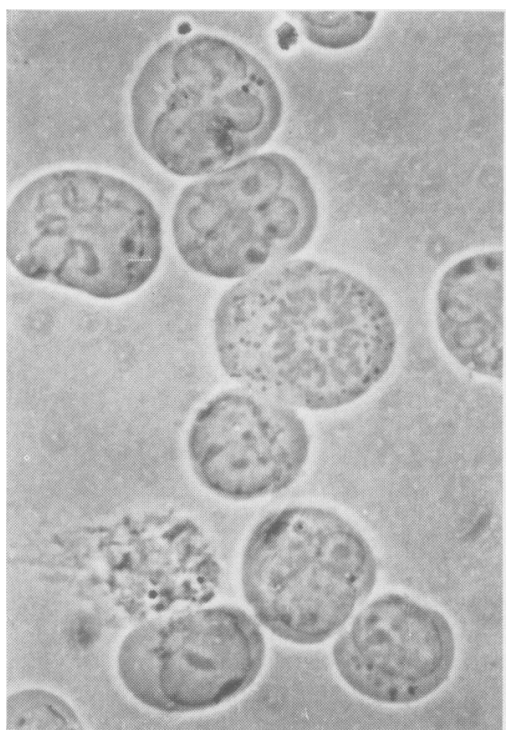

FIG. 3 .

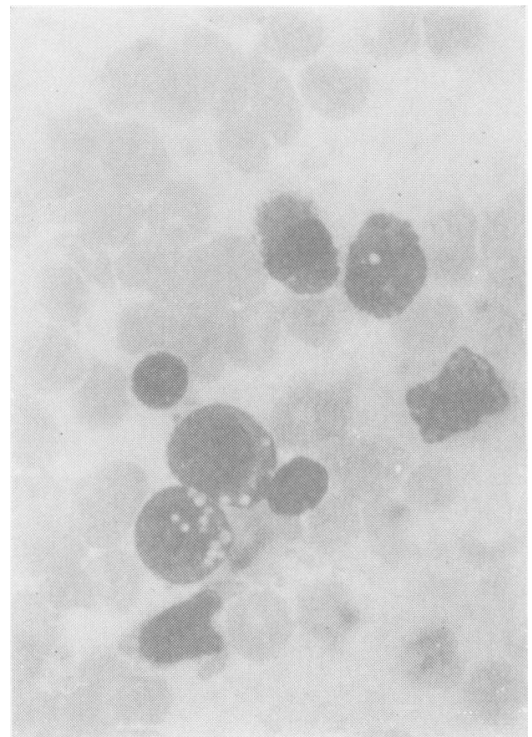

FIG. 5 .

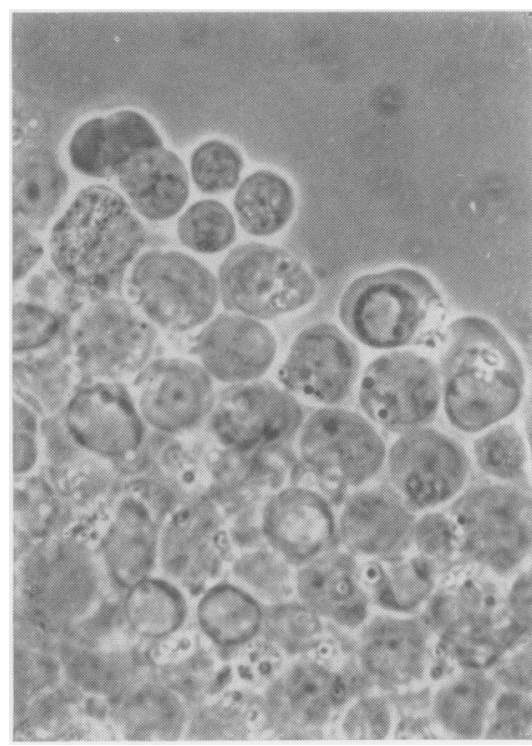

FIG. 4.

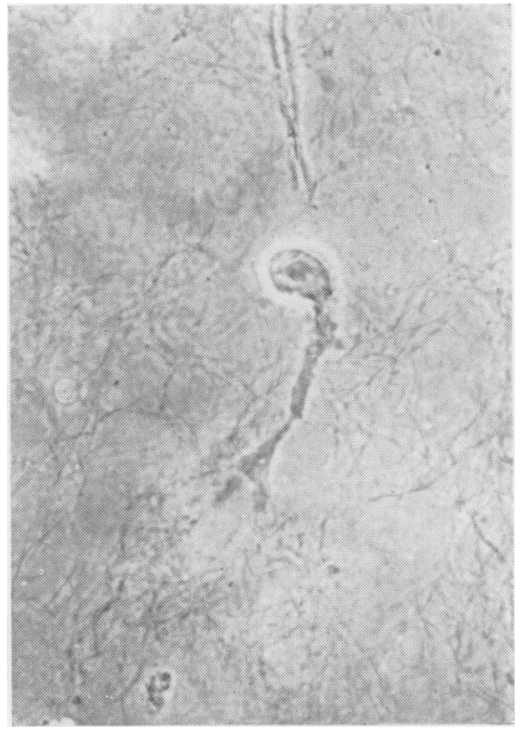

FIG. 6.
FIG. 3. Burkitt cells, fresh preparation on agar from. cerebrospinal fluid $\times 900 \frac{\bar{\Phi}}{\overparen{D}}$ Cells with clear nuclear and cytoplasmic margins, as in this case, usually diequickly.-

FIG. 4. Burkitt cells, fresh $\overrightarrow{\hat{H}}$ preparation from bone marrow, on glass $\times 900$.

FIG. 5. Burkitt cells, stained with Leishman, from bone marrow $\times 900 \frac{\text { 定 }}{2}$

FIG. 6. Burkitt cell, stained with osmic acid ethyl gallate on collagen.
The nucleus contains little phase-positive material, in marked contrast to lymphocytes. It is often indented or trefoil in outline.

When grown on the agar roller slides, a minority of cells survive for a few days but motility is not seen. Mitosis is common, and binucleated forms frequent. When the cells die they often show nuclear cysts, as do dying lymphocytes (Fig. 4). When grown on collagen the cells immediately adhere and although the majority remain motionless an occasional cell becomes very slowly motile, shaped like a sperma? tozoon, moving nucleus forward (Fig. 6). In nearlye all cases the cells slowly die, and after a few weeks none are left alive. Sometimes the cells appear to be intracellular and divide inside investing cells.

In two cases cell lines were isolated, one of which is still active after 15 months (Fig. 7); the second was? recently isolated by Dr. Osunkoya. Both cultureso are identical and are also apparently the same as twQ strains isolated by Epstein and Barr (1964) fromb 


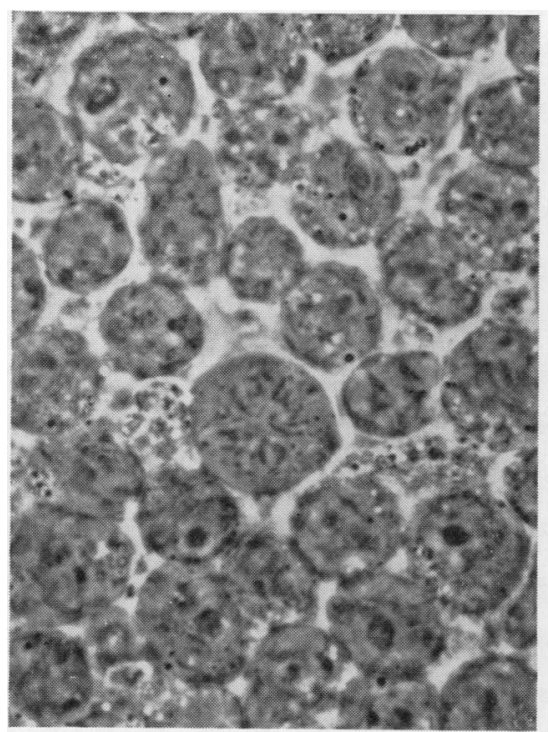

FIG. 7.

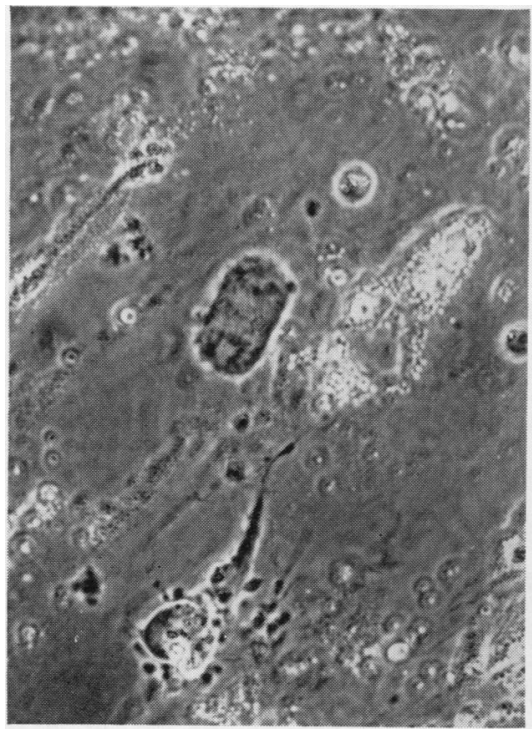

FIG. 9.

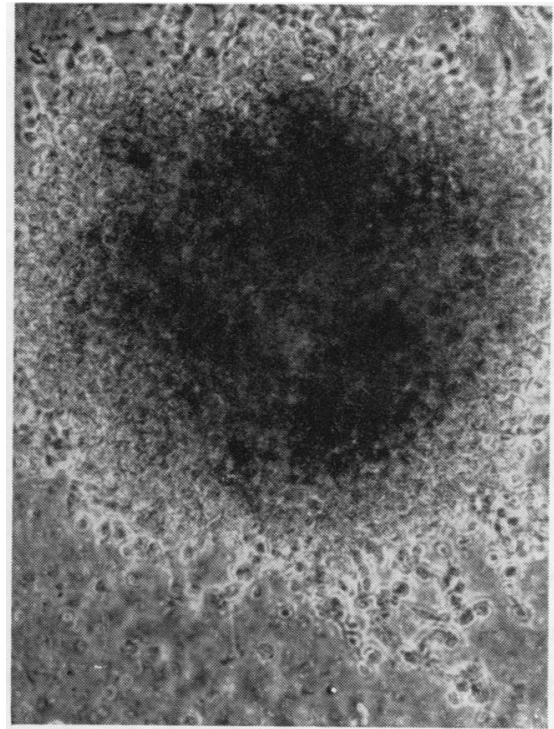

FIG. 8.

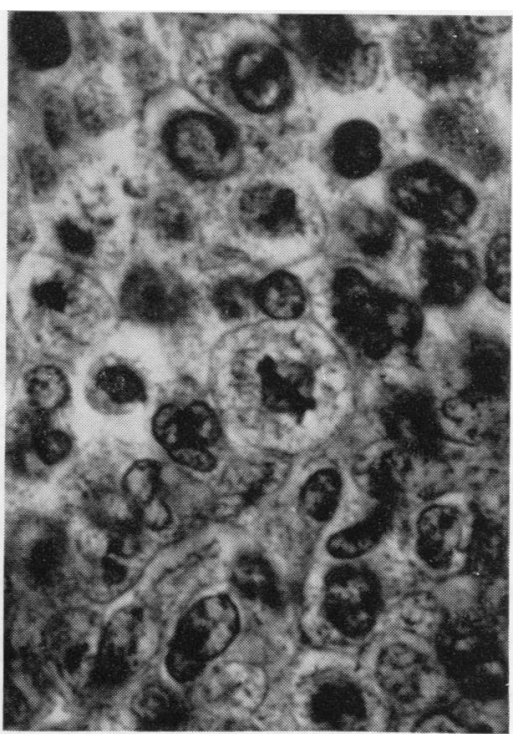

FIG. 10.

FIG. 7. Burkitt cells, cell line 'Raji' on glass. $\times 900$.

FIG. 8. Burkitt cell 'colony' on collagen. $\times 100$.

FIG. 9. Burkitt cell in mitosis under feeder layer of thyroid $\times 900$.

FIG. 10. Burkitt cell line 'Raji' embedded in agar and ester wax. Section cut in thick. Stained osmicacid-ethyl-gallate. $\times 900$. Note spindle cells and mitochondria.

East African material. In both of our cases embryo extract was used in primary cultures, although its use did not establish any other strains. The individual cells differ little if at all from suspensions of cells from tumours and this is of interest because in many, perhaps in most cases, cells in tissue culture become transformed and tend eventually to look like Hela cells. They require human serum, at least $10 \%$, for survival, and although raising the percentage to $30 \%$ produces an immediate increase in the size of the cell, and for a period increased rate of division, the cells soon settle down to their habitual very slow rate of growth.

Cells in culture adhere to each other in spherical clumps, usually with a central hole in old cultures, but the clumps are readily dispersed by gentle agitation, and they never stick to glass. When clumps are planted on to collagen they remain as colonies with a circular outline and serpiginous cells slowly emigrate (Fig. 8). Phyto-haemagglutinin has 
no effect on cultures. They can be maintained in deep freeze without difficulty.

By phase contrast no inclusions resembling virus aggregates are seen either in cell lines or fresh cells. The fresh cells survive well on feeder layers of human thyroid, penetrating through the feeder layer to the glass coverslip and dividing. They never produce visible changes in the feeder layer cells and by this technique never increase greatly in number (Fig. 9).

The behaviour of Burkitt cells in penetrating feeder layers and moving though sluggishly on the glass is seen also in normal lymphocytes which, however, move rapidly under such conditions. This motility is hard to understand as the thyroid cells are so firmly adherent that even brisk agitation in fluids will not dislodge them. It is hard to envisage in what medium they are moving. The cells of mouse leukaemia, although very freely motile, also penetrate feeder layers, and in common with Burkitt cells, autolyse quickly unless a feeder layer is provided by the techniques we have employed. What essential nutrient or physical condition is involved in the survival both of Burkitt cells and those of mouse leukaemia when feeder layers are provided, and what occasions the rapid autolysis of both cells outside the animal or human being, has not been established. The contrast with the robust and long-living small lymphocyte is most marked. In human Burkitt tumours a high proportion of cells are dead when first examined. In cerebrospinal and ascitic fluids all are alive but die quickly in ascitic fluid in vitro.

The cell line first established is centrifuged, embedded in agar and ester wax, and sections are cut. The results are not unlike tumour sections similarly processed and stained, but cells are more loosely packed. Spindles in mitosis are surprisingly well demonstrated (Fig. 10). In a long series of cultures in London a cell line was only once established in a reticulosis. It was from a case of Hodgkin's disease; the cells closely resembled Hela cells and adhered firmly to glass. Therefore in over 100 cases of Burkitt's tumour in Nigeria an identical cell was seen in fresh specimens and in four cases from Africa identical call lines have been established. In no case examined by me in London were cells of this type noted but it must be emphasized that few cases came from children. Of the cases diagnosed by me on cytological grounds as Burkitt's tumour, one, seen early in the series, was certainly wrongly diagnosed, since it was clearly a Wilm's tumour. The others were confirmed by necropsy, section, history, and $x$-ray examination.

It may now be asked what deductions can be drawn from these studies. So far as adult lymphosarcoma and chronic lymphatic leukaemia are concerned, there is really no evidence on cytolo $\frac{0^{*}}{2}$ gical grounds that the conditions are neoplastic. There is no evidence of overproduction of cells $\overrightarrow{\overrightarrow{\vec{b}}}$ which are mature, normal in every way, and aref never seen in mitosis. These diseases are more likely to be related to under-elimination of cells than overproduction. In acute lymphatic leukaemiक्ष there is certainly overproduction; the cells are abnormal in appearance and there is much mitosises In Burkitt's tumour there is again overproduction $\overrightarrow{0}$ as mitosis is invariably seen. But the cells do not resemble any commonly seen in human disease irw London and I have never seen them. They dohowever, closely resemble the cells (Figs. 11 and 12) produced following transformation of human lymeo phocytes by phytohaemagglutinin (Pulvertaft, 1964)

The history of the transformation of lymphocytes by seed extracts is interesting. Agglutination of re $\bar{b}$ cells was noted as long ago as 1888 by Stillmark using castor oil seeds, which by coincidence are called beans, although the plant is a Euphorbian The widespread incidence of this property was. found in leguminous seeds by Boyd and Reguer (1949). Such extracts were used by Rigas and Osgooø (1955) to rid blood and bone marrow cultures of red cells, their property of stimulating lymphocytes nof being known. Among those who recognized this property were Elves, Roath, and Israëls (1963), an Barkhan and Ballas (1963) earlier separated th 8 agglutinating and transforming factors.

In an unpublished time-lapse film, with J. G. Humble (1963), the course of transformation was recorded. Apparently all lymphocytes and on $\overline{\mid c}$. lymphocytes, are transformed, so far as bloof leucocytes are concerned. They become larger and more sluggish, a pronounced nucleolus develops the cytoplasm extends and the nucleolus disappears. Mitosis then occurs and the motionless cells aggre gate in clumps. These do not adhere to glass and are readily dissociated. There are many points of resemp blances to Burkitt cells.

Elves et al. (loc. cit.) suggested that the trans formation was an antigen-antibody reaction, the antibody being in the lymphocytes and the antigen presumably in beans, eaten by everyone. Thes showed that similar transformation could be prơ duced by suitable antigens such as toxoid, tuberculin, and viruses if the patient had been exposed to the relevant antigen previously. The literature on this subject is now large and drug-induced transformation has been described by Holland and Maues (1964) in the lymphocytes from a patient sensitized by phenytoin.

In attempting to relate these new findings to the problem of Burkitt's tumour it is clear that no singe explanation will satisfy all the known facts. Th\& 


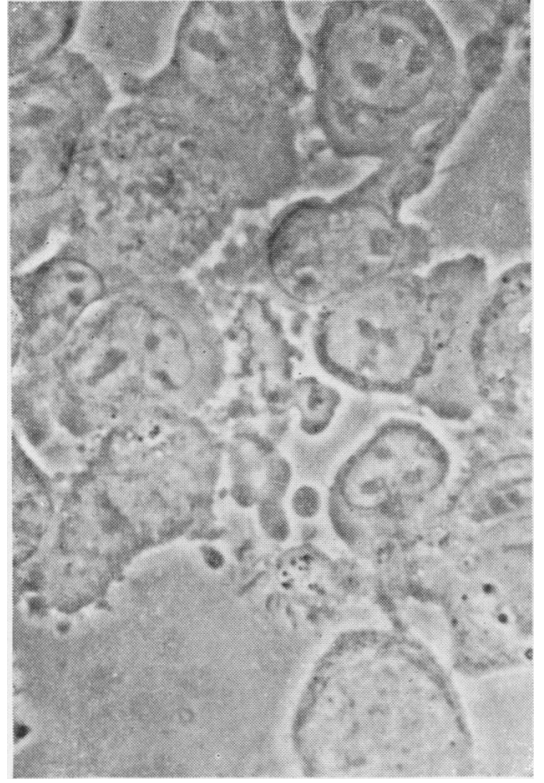

FIG. 11 .

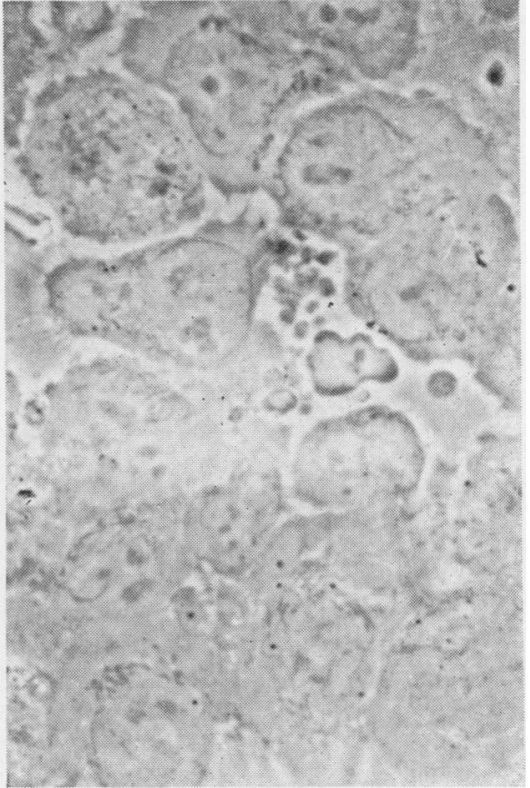

FIG. 12.
FIG. 11. Normal human lymphocytes transformed by phytohaemagglutinin. Agar culture. $\times 900$.

FIG. 12. Burkitt cell line 'Raji' agar culture $\times 900$.

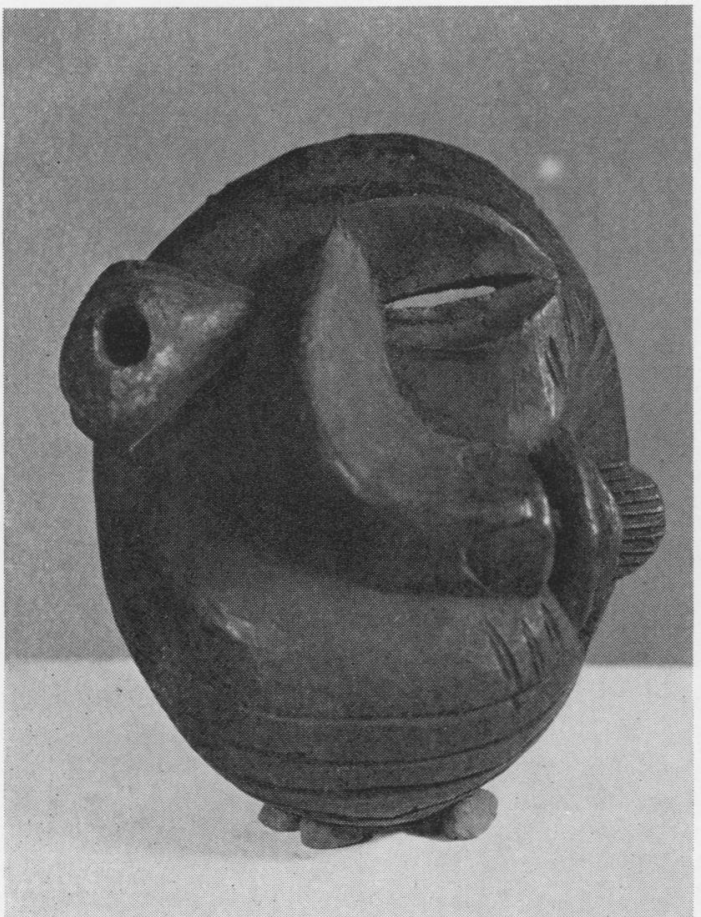

FIG. 13. Wooden mask, traditional form, from Ibadan, $W$. Nigeria. Note proptosis and facial deformity.

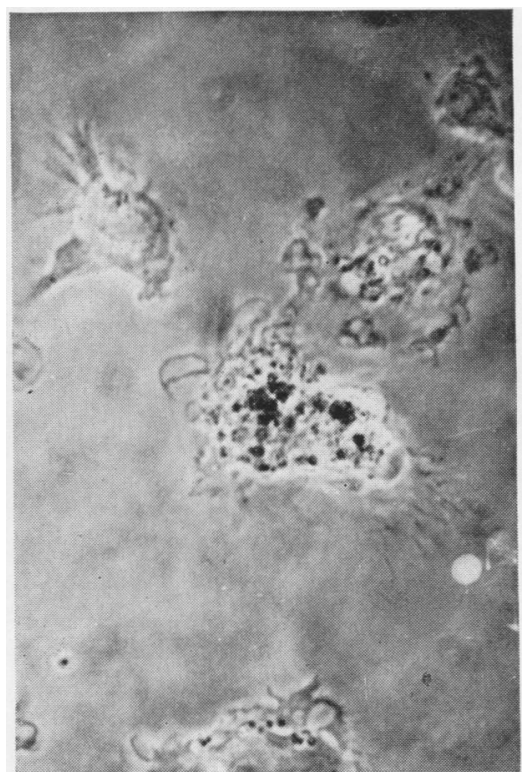

FIG. 14. Monocyte from bone marrow, in a case of Burkitt's tumour. Agar culture. Note malarial pigment $\times 900$. 
tumour is common in Africa and has probably been common since time immemorial, as wooden masks are found showing the typical proptosis and facial deformity (Fig. 13). Its rarity elsewhere is difficult to explain on any hypothesis.

However, the close resemblance of the Burkitt cell to the transformed lymphocyte suggests that among the factors operative might be diet and infection. Although beans are the staple diet in Nigeria, they are eaten everywhere and the association is unlikely though not impossible. Infection is a far more important possibility. In Nigeria malaria is holo-endemic, and all bone marrow cultures show malarial pigment (Fig. 14); enteric fever, tuberculosis, dysentery, both bacterial and amoebic, entero and arbor viruses are exceedingly common. Helminthiasis is universal. From all these conditions and from malnutrition, due to ignorance and not usually to shortage of food, nearly half of the Nigerian children born are dead before the age of 5 years. After this a sturdy and general immunity develops and the adolescent comes to terms with practically the whole repertoire of infectious disorders.

It is not surprising that most workers with firsthand knowledge of Burkitt's tumour have noticed its possible association with infection. It was suggested to me by Professor G. M. Edington and has been commented upon by Metcalf (1962) and by Dalldorf, Linsell, Barnhart, and Martyn (1964) in a paper entitled 'An epidemiological approach to the lymphomas of African children and Burkitt's sarcoma of the jaws'. In this the question is asked, 'May it be possible that an effect of chronic malarial infection of the reticulo-endothelial system has been a different response with the aetiological agent or agents of lymphomas in tropical climates?' An interesting corollary to this suggestion is the peculiar disorder known as 'big spleen disease' which is not infrequent in Nigeria and has been studied by Watson-Williams (1964). He has shown that there is marked response in this condition to Paludrine, involving great reduction in size of the spleen and cure of the anaemia. However one of these patients observed by me, and apparently therapeutically under control, developed a tumour of the sternum, which was histologically a reticulosarcoma, and conformed with this diagnosis on tissue culture. A second case of this type, also seen by me, was fatal and showed at necropsy a single deposit of a malignant reticulosis in the kidney. But all such suggestions leave a great deal unexplained. Why is the disease not as common in the tropics of the New World, in India, and in Asia generally, as in Africa? Why was it not recorded in Europe during the centuries when infections of all kinds, including malaria, was as common as in Africa today? And why is the jaw so commonly affected? Only to the last question is a tentative answer possible. According to Shieham. (1964), who recently made an intensive study of the subject, periodontal disease is practically universal among Nigerian children, although caries is rare The histology of the gums shows lymphocytic infiltration. The stimulus to lymphocytic trans formation may be greatest where chronic inflam 0 mation is present.

Burkitt's tumour is, however, not the only on $\vec{b}$ which presents in the jaws. Retinoblastoma occurswith the same frequency as in England, and severf cases have been cultured. It often presents difficul ties in differential diagnosis, although it appears as a rule in a younger age group, and since rosettes arepo rarely seen, it may be confused in sections with Burkitt's tumour. In culture it invariably grows in branching chains (Fig. 15) and the cells adhere to glass, affording an unequivocal diagnosis. Neuroblastoma is, again, not uncommon, and is confused both clinically and in sections. The appearances in cultures are unique; the faceted cells are adherent to each other and to glass (Fig. 16), and grown ono collagen show the typical fine processes (Fig. 17) described by Murray and Stout (1940). Adamantinoma occurs in adults, and in Nigeria often grows to a great size. There is no difficulty in clinicab diagnosis. The epithelial cells can be dispersed byő collagenase (Fig. 18) but up to the present haves survived poorly. The stellate connective tissue cells survive very well.

Fibrous displasia occurs in the mandible, and both osteoclasts (Fig. 19) and connective tissue cells are readily cultured following dispersal with collagenase Inflammatory conditions, especially in the maxilla? present clinical problems but on tissue culture the familiar pattern, a mosaic of inflammatory cells. easily excludes Burkitt's tumour.

Leukaemia with orbital involvement was once seen (Fig. 20). At necropsy one deposit was green? but it was not a typical chloroma. The bone marrow showed exclusively motile and glass adherent cells (Fig. 21). I would classify them as myeloblasts.

It is significant that the bony lesions of Burkitt's tumour, which are so common, are never continuous as in leukaemia but occur in separate non-confluent areas. This has suggested to many, and to me, multifocal origin. In this the condition is reminiscene of multiple myelomatosis, which was seen on many occasions. The malignant cells are quite different in culture from plasma cells (Fig. 22) where the mito chondria are fine and always arranged so as to leave a bare area near the nucleus, the 'juxta nuclear halo을 of haematologists, and they are not motile. In myelo? matosis the cells are much larger and motile. Theig 


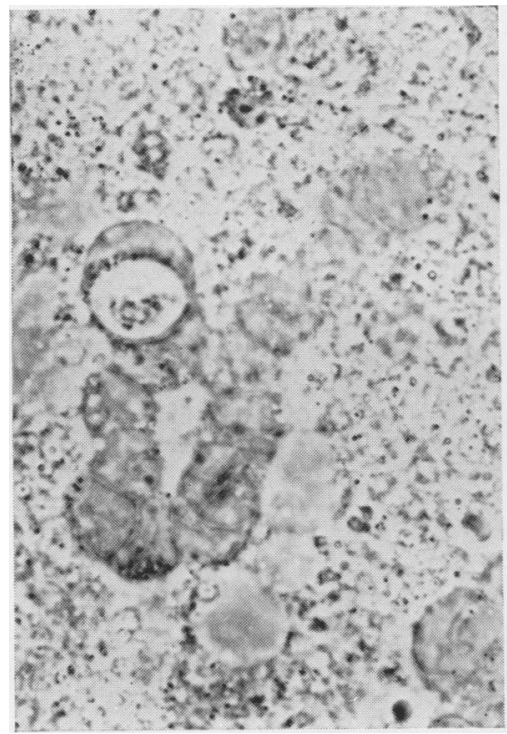

FIG. 15 .

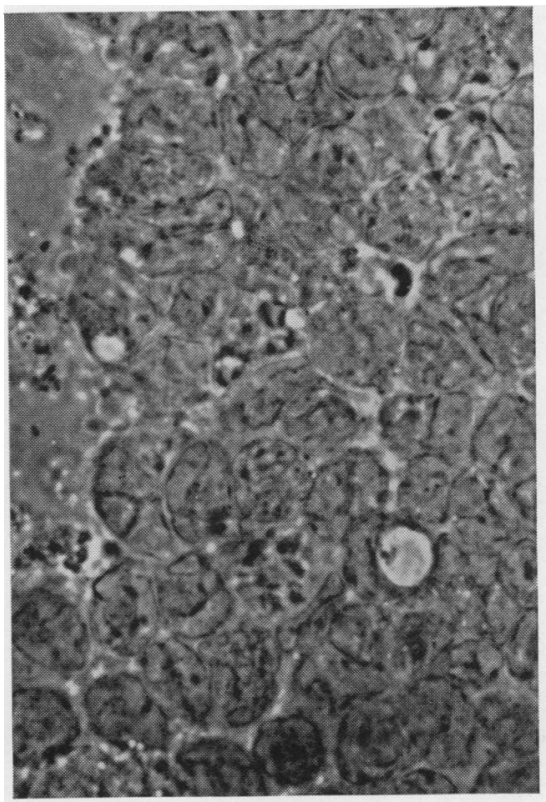

FIG. 16.

FIG. 15. Retinoblastoma, primary culture on collagen. $\times 900$.

FIG. 16. Neuroblastoma, primary culture on glass. $\times 900$.

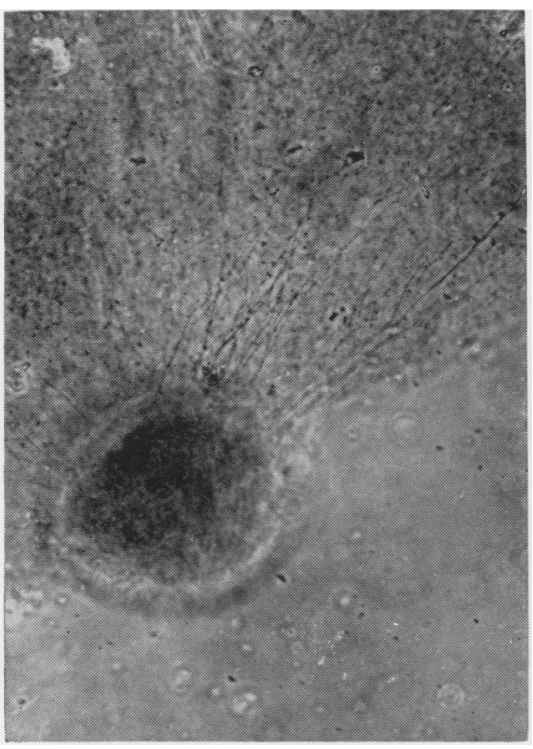

FIG. 17.

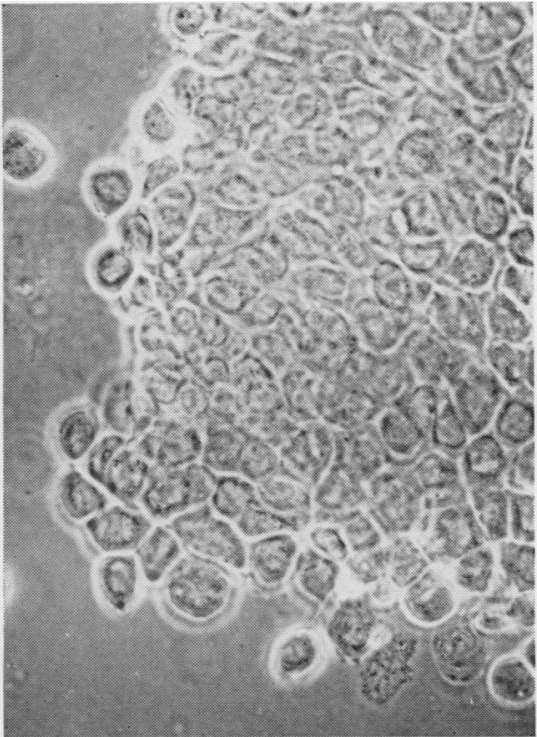

FIG. 18.

FIG. 17. Neuroblastoma, colony on collagen to show neurofibrils. $\times 100$.

FIG. 18. Adamantinoma dispersed by collagenase. Cells on glass immediately after dispersal. $\times 400$. 


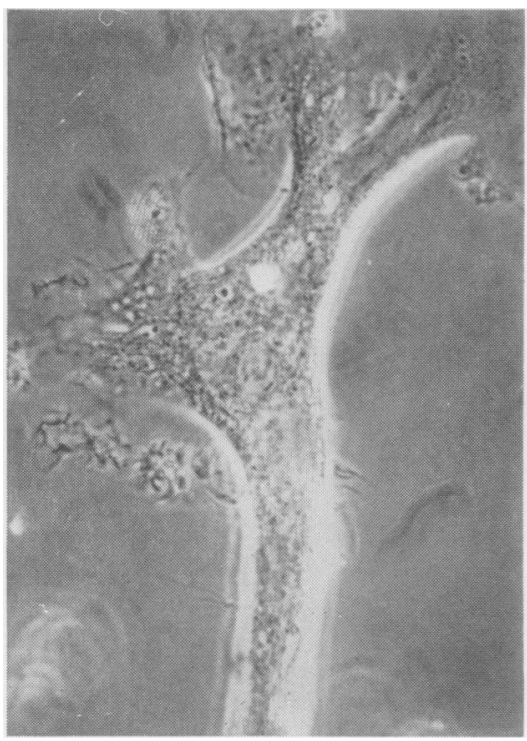

FIG. 19. Fibrous displasia of mandible. Motile osteoclast (only part of cell is shown). Glass culture $\times 900$.

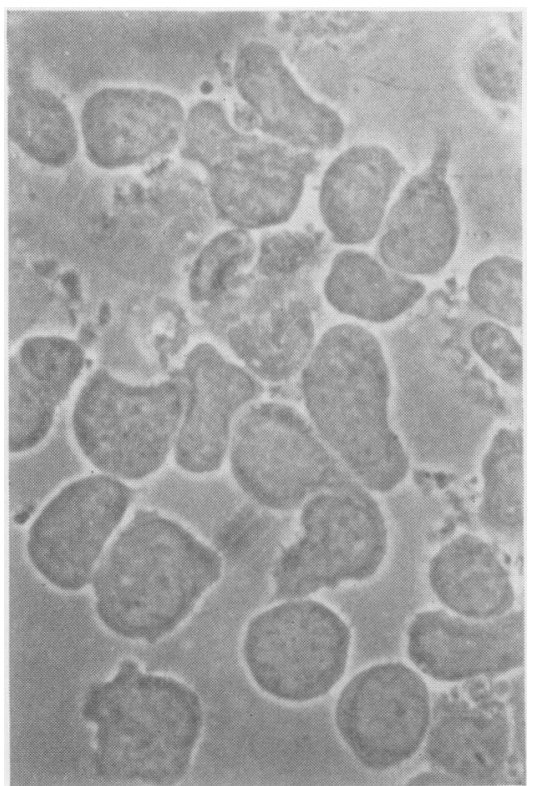

FIG. 21. Leukaemia, bone marrow culture on agar from case shown in FIG. 20. $\times 900$. 


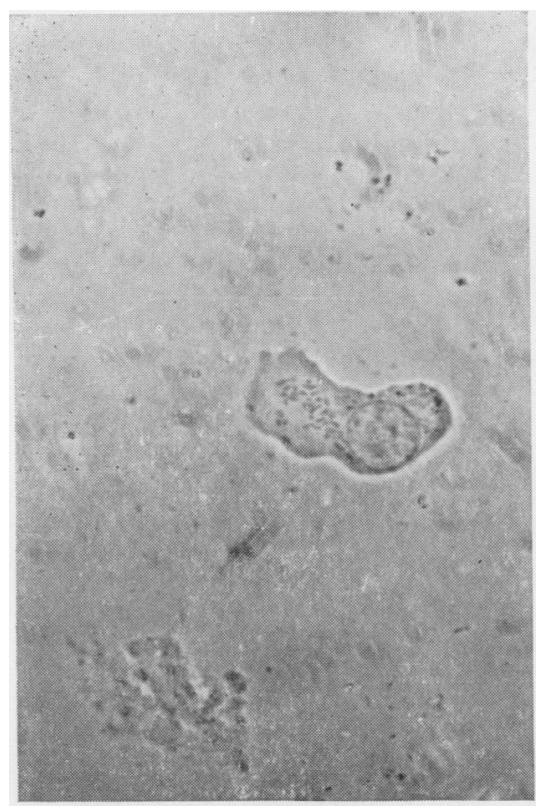

FIG. 23.

Bone marrow, multiple myelomatosis. Culture on agar. Motile myeloma cell. $\times 900$.

outstanding features are the very thick stubby mitochondria (Fig. 23).

Wilm's tumour has been commonly seen, but has presented neither clinical nor histological problems. It is readily grown in tissue culture.

In conclusion, there are two points which I wish to stress. A popular view is that this is an arthropodspread virus tumour. The view expressed here, which does not exclude the virus factor, is that overstimulation of the lymphopoietic system by multiple infection, and possibly the dietetic factor involved by the use of beans as a source of protein, must be seriously considered. From the point of view of prophylaxis, advances in hygiene, and particularly in malaria control and mosquito elimination, might be equally efficacious whether viruses alone or viruses in conjunction with infection, are involved.

The second point is more important. Malignant disease, in Africa as everywhere else, is an unsolved problem. So far as public health expenditure is concerned, it comes low on the list of priorities. The spread of instruction on hygiene, the control of malnutrition due to ignorance, and of malaria and all other protozoal, viral, and helminthic disorders, are far more important. The disease is a terrible one, killing within six months from the onset, with gross facial deformity and extreme discomfort. But there are other problems whose solution is both more important and more certain.

The importance of the study of malignant diseases in Africa is not in relation to the interests of Africans but of all humanity. Malignancy presents in Africa in a different manner from elsewhere, some types excessively rare elsewhere being there common, others, such as the rodent ulcer and bronchogenic cancer, are either unknown or very rare.

Sir Thomas Browne has said that Nature discloses her secrets most readily when she manifests herself in an exceptional way. It is for this reason that studies far more intensive than have hitherto been possible are urgently required. Research workers might far more profitably spend their time in tropi$\mathrm{cal}$ areas in Africa than in the thrice ploughed fields of temperate climates.

I have been impressed very deeply by the scientific and technical qualities of Nigerian graduates. In time I have no doubt whatever that they will establish and develop centres where all these problems will be studied with every possible degree of expertise. But I am sure that few investments are more likely to yield a return in the laboratory field, in the meantime, than in tropical medicine. Only the surface has been scratched; there are still rich seams to be mined.

This work was undertaken with the help of a whole-time grant from the British Empire Cancer Campaign for Research.

My thanks are due to Professor G. M. Edington for hospitality and advice, and to all my colleagues in the Department of Pathology, University of Ibadan and University College Hospital, Ibadan. All the technical work was undertaken by my wife, Elizabeth Pulvertaft. The photographic prints were provided by the Medical Illustration Department, University of Ibadan.

The wooden mask illustrated was discovered by Dr. G. W. Spiller; similar masks are in the museum at Lagos. The case of C. L. Coroma was under the care of Dr. A. C. Ikeme.

\section{REFERENCES}

Barkhan, P., and Ballas, A. (1963). Nature (Lond.), 200, 141.

Boyd, W. C., and Reguera, R. M. (1949). J. Immunol., 62, 333. Burkitt, D. (1958). Brit. J. Surg., 46, 218.

Dalldorf, G., Linsell, C. A., Barnhart, F. E., and Martyn, R. (1964). Perspecto Biol. Med. 7, 435

Edington, G. M., and Maclean, C. M. U. (1964). Brit. med. J., 1, 264. Ehrmann, R. L., and Gey, G. O. (1956). J. nat. Cancer Inst., 16, 1375. Elves, M. W., Roath, S., and Israëls, M. C. G. (1963). Lancet, 1, 806. Epstein, M. A., and Barr, Y. M. (1964). Ibid., 1, 252.

Holland, P., and Mauer, A. M. (1964). Ibid., 1, 1368.

Lewis, Margaret R., and Lewis, W. H. (1911). Bull. Johns Hopk. Hosp., 22, 126.

Lumsden, C. E. (1963). In Pathology of Tumours of the Nervous System, 2nd ed. edited by D. S. Russell, and L. J. Rubinstein, p. 281. Arnold, London.

Metcalf, D. (1962), Austr. Ann. Med., 11, 211.

Murray, M. R., and Stout, A. P. (1940). Amer. J. Path., 16, 41.

O'Conor, G. T., and Davies, J. N. P. (1960). J. Pediat. 56, 526.

Pulvertaft, R. J. V. (1959). In Modern Trends in Pathology, edited by D. H. Collins, p. 19. Butterworth, London.

- (1964). Phytohaemagglutinin in relation to Burkitt's tumour (African Lymphoma). Lancet, $2,552$.

Rigas, D. A., and Osgood, E. E. (1955). J. biol. Chem., 212, 607.

Russell, D. S., and Bland, J. O. W. (1933). J. Path. Bact., 36, 273.

ten Seldam, R. E. S. (1964). Unpublished communications to W.H.O. Shieham, A. (1964). Personal communication.

Stillmark, H. (1888). Ueber Ricin, ein giftiges Ferment aus den Samen von Ricinus comm. L. und einigen anderen Euphorbiaceen. Inaugural Dissertation. Schnakenburg, Dorpat.

Watson-Williams, E. J., (1964). Personal communication.

Wright, D. H. (1963). Brit. J. Cancer, 17, 50. 


\section{Appendix}

\section{Use of roller slides for cytology and short-term tissue culture}

This technique is most valuable for the study of bone marrow, but is also useful for the study of any cells, particularly of lymph nodes. The advantages of the method are: (1) that cells can be squeezed flat on agar without damage, and (2) that cells are repelled by agar and attracted by glass, and are therefore all in one optical plane. The thin layer of agar does not greatly interfere with phase microscopy. Agar was first used in tissue culture by Lewis and Lewis (1911).

\section{APPARATUS}

PHASE CONTRAST MICROSCOPY WITH LONG WORKING DISTANCE CONDENSER Instruments of this kind are made by Cooke, Troughton \& Simms, St. James's Park, London, and by many continental firms. An $\times 50$ fluoride oil immersion objective is desirable.

MICROSCOPE INCUBATOR This can be made readily out of perspex, and is heated by a low wattage lamp. The thermostat used is the Sunvic with its outer case removed. The temperature should be regulated to $36^{\circ} \mathrm{C}$., as any rise above $37^{\circ} \mathrm{C}$. is dangerous. Openings must of course be available for all adjustments.

REAGENTS The agar used must be a purified brand (e.g., Noble agar) or other agars used in microbiology. Many agars used in bacteriology are toxic. The agar is made up at $3 \%$ in conductivity water.

SERUM Adult human serum is the best choice, and is alone suitable for Burkitt's tumour. For most human tumours horse serum has been found satisfactory.

SALT MIXTURE It is convenient to use '199,' which can be purchased in concentrated form from Glaxo, Greenford, Middlesex.

DILUENT All water used must be first distilled and then de-ionized, i.e., conductivity water.

CULTURE MEDIUM This consists of $30 \%$ of serum in ' 199 ,' which already contains penicillin and streptomycin. In the tropics Neomycin, 100 units per ml., and Nystatin must be used, in accordance with the printed instructions sold with the agent. Nystatin is unstable and ineffective if its particles are allowed to aggregate. It must therefore not be kept frozen, and preferably kept at $4^{\circ} \mathrm{C}$. for not more than 14 days.
CleANING of GLASSWARE Consult any standard tissue culture textbook, preferably that of Paul, Edinburgh. Two. detergents are suitable, namely Haemosol and Alkonit

STERILIZATION All glassware is sterilized by dry heat op autoclave. The serum is not filtered, but Neomycin and Nystatin are added and it is preserved frozen at $-20^{\circ} \mathrm{C}$, Each bottle of serum must be cultured before use and the test cultures retained for three days.

STERILIZATION OF CULTURE CHAMBER Since this is made of perspex it cannot be boiled or autoclaved. It is heated. to $60^{\circ} \mathrm{C}$. in Haemosol solution, washed with conductivit $\vec{w}$ water, and dried at $37^{\circ} \mathrm{C}$. Chambers are kept in covered? metal boxes until used.

CULTURE CHAMBER This resembles a blood counting chamber with two lateral openings. The central pillar must be carefully polished. The dimensions of the chamber are not critical, but the ones in use have the following measurements:

Length $\ldots \ldots \ldots \ldots \ldots \ldots \ldots \ldots, 7.5 \mathrm{~cm}$.

Breadth ........................

Depth $\ldots \ldots \ldots \ldots \ldots \ldots \ldots \ldots \ldots \ldots \ldots \ldots$ cm.

Diameter of central pillar .......... $2.5 \mathrm{~cm}$.

Diameter of culture chamber ......... $3.5 \mathrm{~cm}$. Central pillar is $2-3 \mathrm{~mm}$. below level of slide.

Three small depressions in pillar to fix the agar.

\section{USE OF CHAMBER}

The culture medium is warmed to $37^{\circ} \mathrm{C}$. and the agar isD melted and cooled to $50^{\circ} \mathrm{C}$. With a hot pipette, 1 part of melted agar is added to 2 parts of culture medium and rapidly mixed, avoiding formation of bubbles. The culture chamber is filled with the molten agar and a large glass slide is then applied to flatten the agar. A very thin film? of agar now remains between the glass slide and perspex surface, and when this is later removed the level of the agar in the central container is slightly above that of the perspex. The chamber is now placed in a refrigerato ${ }^{3}$. until the agar is set.

\section{APPLICATION OF MATERIAL FOR STUDY}

Bone marrow is collected in heparinized medium an allowed to stand in a small Petri dish for 15 minutes. In most cases marrow particles rise to the surface and aref collected in a pipette and washed in fresh medium: The particles are later placed on the prepared agaro surface. If there are no particles, the bone marrow sample is centrifuged in a Wintrobe tube and the buffyo coat is used for inoculation. This is usually less satisfactory.

Other material must be treated secundum artem, and treatment will depend upon the nature of the material: For example, cells from lymph nodes are collected by dispersal in culture medium by squeezing with forceps blades; many tumours, e.g., malignant melanoma and carcinoma of the thyroid, can be dispersed with trypsin ${ }_{D}$ and soft tissue tumours are dispersed by collagenase (Worthington Manufacturing Company, U.S.A.) It is not possible to go into further details here. 
SPECIAL TREATMENT

Bone marrow specimens require no further treatment, but material from lymph nodes and such types of sarcoma as the Burkitt tumour often show much autolysis. A sample should therefore be planted on the agar, and the remainder of the tissue cells dispersed as above are inoculated into $20 \mathrm{ml}$. of culture medium in a stoppered bottle. Eighteen hours later autolysis has ceased and the culture is centrifuged, washed once in culture medium, and the deposit planted.

\section{AMOUNT OF INOCULUM}

The cells should be inoculated with a fine Pasteur pipette as it is essential that there should be a central focus of cells from which cells can migrate. At least four foci can be planted in one container.

\section{FINAL PREPARATION OF CHAMBER}

The chamber will now be filled with agar, both over the pillar and in the surrounding trough. The agar is removed from the trough with a scalpel and high vacuum silicone grease is applied thinly around the trough. Four small pillars of grease are also made at the four corners of the trough.

The material for culture is placed on the agar and a cover slip applied to rest on the four pillars. The culture chamber is then inverted and the cover slip is firmly pressed down on a blotting paper pad with a slight rotary movement. There should now be only a small capillary space of approximately $50 \mu$ between cover slip and agar. Failure to obtain good results is most often due to the fact that there is too much space between the agar and the cover slip.

After removal of surplus silicone the cover slip is sealed down with beeswax. Paraffin must not be used.

SEALING OF LATERAL APERTURES These must be sealed with Parafilm over-sealed with beeswax. The seals must be applied before adding the agar as otherwise they will be blocked.

INCUBATION The preparations must be kept with the cover slip downwards for at least five hours, after which they can be examined under the microscope in the hot box. After 18 hours culture medium is added to fill half the trough, and the lateral apertures are again sealed.

The best results are now obtained by fixing the culture chamber in a vertical position and rotating it once every three minutes while the preparation is not being examined. The culture medium is replaced daily with warm medium.
RESULTS

Bone marrow cells usually retain their original morphology and relative numbers for $\mathbf{4 8}$ hours, after which both characteristics change, especially with regard to relative numbers of cell types.

It is not possible to generalize about other cell behaviour. Certain material may be in cultured form as long as two months. Lymph node material has only a short life.

\section{RING CHAMBERS}

These are made of any suitable plastic material, e.g., Klingarite (Klingers, Chislehurst, Kent). The diameter is $3 \mathrm{~cm}$. and the depth $3 \mathrm{~mm}$. The ring is fixed to a microscope slide with high vacuum, silicone greased and filled with a cellular suspension of approximately 200,000 cells per $\mathrm{ml}$. The cover slip is then applied to the ring surface covered with silicone grease. It is important to avoid bubbles. The chamber is incubated cover slip downwards, but if the cells are not glass adherent the cells must be examined in an inverted microscope.

\section{COLLAGEN-COATED COVER SLIPS}

Collagen solution is prepared from the tendons of rats' tails, essentially by the technique of Ehrman and Gey. Take two large rats, cut off the tails, remove skin and fracture the tails in six places with pliers. Remove the four tendons with their sheaths and cut up finely with scissors.

Add $0.1 \mathrm{ml}$. of glacial acetic acid to $150 \mathrm{ml}$. of conductivity water and leave stoppered at $4^{\circ} \mathrm{C}$. for 48 hours, with frequent agitation. Centrifuge strongly and pour supernatant into dialysing sacks. Dialyse for $\mathbf{4 8}$ hours.

The fluid should now be quite viscid. If it is not, it is no use. At this stage add Neomycin and Nystatin as collagen is very readily contaminated.

To the cover slip mounted on a ring is added 0.75 $\mathrm{ml}$. of collagen solution, making sure that the whole surface is covered. It is then placed overnight in a desiccator in an atmosphere of ammonia vapour. The next morning there should be a firm gel covering the cover slip.

The chambers are now placed in a desiccator until quite dry when a very thin film of collagen will be found to cover the glass. The ring is now filled with culture medium and the microscope slide applied. The gel reforms and the containers can be kept indefinitely at $4^{\circ} \mathrm{C}$.

FOR USE The medium, which will be strongly alkaline, is discarded and either tissue fragments or cell suspensions can be cultured. All live cells adhere to collagen. Many tumours produce collagenase, but as a rule only after several weeks' incubation. 